\title{
SOME DIFFICULTIES FACED BY THE STUDENTS IN LEARNING PRESENT PERFECT TENSE
}

\author{
Mar'atus Sholeha ${ }^{1}$, Edi Ardian $^{3}$, Samsul Amri $^{3}$ \\ English Study Program \\ Universitas Islam Indragri-Tembilahan Riau ${ }^{1.2 .3}$
}

\begin{abstract}
The research purpose is to know the difficulties faced by the students in learning Present Perfect Tense and the cause of the problems. The design of the research is descriptive research. The number of the population was thirty-six students. The researchers used tests, questionnaires, and interviews to collect the data. After analyzing the data, it found that the average score of test results was 44.67, which was classified as a less classification. Then the ability in using $\mathrm{To} B e$ (Has/Have) of present perfect tense was placed in a good rating by the mean score 68.29. Moreover, the students' ability in understanding regular verbs was in a less classification by the mean score 34.03 . It also happens for the knowledge in understanding irregular verbs which were classified as less classification by the mean score 39.72. Based on the data obtained from the questionnaires, it shows that most of the students felt that Present Perfect Tense is a problematic material of English. It was proven by seeing that more than $50 \%$ of the students said that. It caused by some factors; (1) English materials are less favoured by the students, (2) they are lack of English vocabulary mastery, (3) they have difficulties in recognizing to be of Present Perfect Tense, and (4) they could control the form of verbs changes.
\end{abstract}

Keywords: Learning Difficulties, Present Perfect Tense

\section{INTRODUCTION}

As an international language, every student from all over the world learns English. In Indonesia, English has been one of the subjects that are essential in each education level. Thus students should master it as a subject school. On the development, teaching English in Indonesia covers a wide range of subject materials which one of them is Tenses.

Tenses are verbs changes to express a close event that is related to the time of the incident. Broadly, tenses can be divided into two parts: past and present, but in general can be divided into three: past, present, and future. Wicaksono (2010:232) said that tenses are a description or explanation of when a declaration, act, or event occurs. The tense forms from which was learned by the students consist of sixteen kinds. In reality, it makes the students 
become confuse how to use them correctly in both written and spoken areas. A study by Hermayawati (2010:1) reflects that there is a feeling forced which is perceived by the students in learning English. Tenses are used to express events or activities performed by the subject at present, the progress, the last time, the scheduled time, and others. This event is outlined in a sentence with a verb form which differs according to the tenses patterns.

Present Perfect Tense is one of the tenses that is required to learn in English. It states an action or activity done, but continue in the present. Past events influence the present (Wicaksono, 2010:242). The verb forms of this tense are in the third verb form (past participle) which means has happened.

In reality, Present Perfect Tense is a type of tenses which is difficult to be mastered by the students either students of junior high schools or senior high schools. However, some of them can use it well. Therefore, in this study, the researchers were interested in finding out the students' difficulties in learning Present Perfect Tense, and the causes of the problems.

\section{LITERATURE REVIEW}

\section{Grammar in English}

Grammar is one of the language components that is important in learning a language. Without mastering it well, someone will find difficulties in understanding an expression both in written and spoken forms. According to Swan (2005:1), grammar is simply a matter of word and sentence building. Therefore, it is one of the compulsory subjects taken by students. In mastering it, there are various selected topics such as part of speech, conditional sentences, tenses, and others.

\section{Tenses}

English tenses aim to show the time (present, past, or future) as well as the occurrence of an event. According to Wicaksono (2010:232), tense is an illustration when a statement, action, event, or news happens or takes place in the sentence of the present, past, or future. Tenses consist of three major parts: past, present, and future, which are divided into sixteen categories, such as below: 
Table 1 Tenses Classification

\begin{tabular}{|c|c|c|}
\hline No & Major Parts & Kinds of Tenses \\
\hline 1 & Present Tense & $\begin{array}{ll}\text { 1. } & \text { Present Tense } \\
\text { 2. } & \text { Present Continuous Tense } \\
\text { 3. } & \text { Present Perfect Tense } \\
\text { 4. } & \text { Present Perfect Continuous Tense }\end{array}$ \\
\hline 2 & Past Tense & $\begin{array}{ll}\text { 5. } & \text { Past Tense } \\
\text { 6. } & \text { Past Continuous Tense } \\
\text { 7. } & \text { Past Perfect Tense } \\
\text { 8. } & \text { Past Perfect Continuous Tense } \\
\text { 9. } & \text { Past Future Tense } \\
\text { 10. } & \text { Past Future Continuous Tense } \\
\text { 11. } & \text { Past Future Perfect Tense } \\
\text { 12. } & \text { Past Future Perfect Continuous Tense }\end{array}$ \\
\hline 3 & Future Tense & $\begin{array}{l}\text { 13. Future Tense } \\
\text { 14. Future Continuous Tense } \\
\text { 15. Future Perfect Tense } \\
\text { 16. Future Perfect Continuous Tense }\end{array}$ \\
\hline
\end{tabular}

\section{Present Perfect Tense}

According to Supono (2007:255), Present Perfect Tense is a tense that describes the events that have taken place at the current time but unspecific time. In line with this view, Wicaksono (2010:242) says that it is a sentence that states the events that occurred on this day and has completed. Thus, it is one of the tenses in English, which means that en event has finished occurred at the unparticular time. Informing the Present Perfect Tense could see the following patterns:

Table 2 Present Perfect Tense Formulas

\begin{tabular}{|c|c|c|}
\hline No. & Forms & Formula \\
\hline 1 & Positive & $\begin{array}{l}\text { Subject+Have/Has }+\mathrm{V}_{3}+\mathrm{Complement} \\
\text { I have given a book to him. } \\
\text { Subject+Have/Has+Been+Non-Verb+Complement } \\
\text { Elly has been here just now. }\end{array}$ \\
\hline 2 & Negative & $\begin{array}{l}\text { Subject+Have/Has+NOT }+\mathrm{V}_{3}+\text { Complement } \\
\text { I have not given a pen to him. } \\
\text { Subject+Have/Has+NOT+Been+Non-Verb+Complement } \\
\text { Michael has not been here just now. }\end{array}$ \\
\hline 3 & Interrogative & $\begin{array}{l}\text { Have/Has+ Subject }+\mathrm{V}_{3}+\mathrm{Complement?} \\
\text { Have you given a pen to him? No, I have not. } \\
\text { Have/Has+ Subject+Been+Non-Verb+Complement? } \\
\text { Has Elly been here just now? Yes, She has }\end{array}$ \\
\hline \multicolumn{3}{|c|}{ Notes: Non Verbs can be adjective, noun, or adverb } \\
\hline
\end{tabular}




\section{Learning Difficulties}

Learning difficulties are also called learning disabilities which have a mean inability to learn. According to Lloyd (1985) in Suryani (2010:33), learning difficulties are a disorder in one or more psychological processes that include the use of language understanding and speech or writing. While, Hammill (1981) in Suryani (2010:33) said that learning difficulties are diverse forms of the real problem in listening activities, conversation, reading, writing, reasoning, and in numeracy.

There are some difficulties experienced by some students in learning English, as pronunciation, vocabulary, conversation, grammar, and others. According to Khaljoo (2013:56-57), the difficulties in learning English for the students are lack of interest and motivation for learning English, lack of concentration in class, students who are ahead of others and most English teachers lack the proficiency in English.

In learning English, students must try harder because they have to learn many new things such as new vocabulary, pronunciation, and grammar. Difficulties in learning English over the years are difficult to understand and comprehend certain materials. Tenses always exist from the elementary to high schools. Besides, reading and listening are also considered as English learning difficulties.

\section{Learning Difficulties of Present Perfect Tense}

As mentioned before, the Present Perfect Tense is one of the selected materials for learning English that most of the students usually find difficulties in mastering it. Martin Parrot (2010:162) says that learners generally have far more problem in using Present Perfect Tense correctly than in understanding it. Even if they do not know or are unclear about the difference in meaning between different tenses, in most cases, there is plenty of information in the context to help them understand whether, for example, an action is temporary or not.

Based on some theories, there are two main difficulties in learning Present Perfect Tense: 


\section{Difficulty in forming Present Perfect Tense}

The form of Present Perfect Tense is subject+have/has+past participle $\left(V_{3}\right)$. To be Have is used for subjects I, We, They, and You. Meanwhile, to be Has is used for subjects She, He, and It (Murphy, 1985:26). In reality, some students still have difficulties in understanding the form of Present Perfect Tense. Here are the examples of mistakes made by the students:

a. I has lost my chance to study abroad.

b. She have finished her homework.

The sentences above are incorrect because the student uses to be "has" for the subject I and to be "have" for subject She. They must be as below:

a. I have lost my chance to study abroad.

b. She has finished her homework.

Moreover, the difficulties in learning Present Perfect Tense in forming verbs are either regular or irregular verbs of the past participle $\left(\mathrm{V}_{3}\right)$.

a. Regular verbs. The simple past $\left(\mathrm{V}_{2}\right)$ and past participle $\left(\mathrm{V}_{3}\right)$ of regular verbs end in-ed. For example: clean (vase form) - cleaned (simple past) - cleaned (past participle).

b. Irregular verbs.

1) All forms (base form $\left(V_{1}\right)$, simple past $\left(V_{2}\right)$, and past participle $\left(V_{3}\right)$ ) are the same. For example: hit (base form) - hit (simple past) - hit (past participle).

2) The simple past form $\left(V_{2}\right)$ is the same as the past participle form $\left(V_{3}\right)$, but they are different from the base form $\left(\mathrm{V}_{1}\right)$.

For example: tell (base form) - told (simple past) - told (past participle).

3) All forms (base form $\left(\mathrm{V}_{1}\right)$, simple past $\left(\mathrm{V}_{2}\right)$, and past participle $\left(\mathrm{V}_{3}\right)$ ) are different. For example: break (base form) - broke (simple past) - broken (past participle).

\section{Difficulty in using Present Perfect Tense}

In learning tenses, the students must be able to distinguish every tense in English, especially between Present Perfect Tense and Simple Past Tense. They are closely related because both are talking about activities in the past time. The example of students' mistake in using Present Perfect Tense is She has lived in Jakarta last year. This sentence is 
incorrect because the sentence uses a specific time (last year). There two options for correcting the sentence:

a. She lived in Jakarta last year (Simple Past Tense)

b. She has lived in Jakarta (Present Perfect Tense)

\section{RESEARCH METHOD}

Type of the research is descriptive research that describes the difficulties of students in learning Present Perfect Tense. The samples of the study were the eleventh-grade students of the Multimedia program of SMKN 1 Tembilahan. In collecting the data, the researchers used a test which is in the multiple-choice form, questionnaire which is in the Gutman Scale form, an interview which is in a structured way. The data were analyzed using descriptive statistical analysis and qualitative data analysis.

\section{FINDINGS AND DISCUSSION}

\section{Validity and Reliability Testing}

One of the requirements of an accepted instrument is valid and reliable. Before taking the real test, the researchers conducted tryouts of the test used to gain if it is accurate and reliable. After analyzing the data, it was found that all items are valid, which could be categorized accepted as a research instrument because the items have facility value ranging from $0.30-0.70$. The test was also reliable because the results of reliability testing were 0.52 , which was categorized as a moderate level.

\section{Results of the Test}

After testing the validity and the reliability of the test, then it found the data of the real test. They must complete thirty items. The results were as below:

Table 3 The Students' Test Results

\begin{tabular}{|c|c|c|c|c|}
\hline No & Level of Ability & Interval Score & Frequency & Percentage \\
\hline 1 & Very Good & $81-100$ & 6 & $16.6 \%$ \\
\hline 2 & Good & $61-80$ & 1 & $2.78 \%$ \\
\hline 3 & Enough & $41-60$ & 10 & $27.8 \%$ \\
\hline 4 & Less & $21-40$ & 18 & $50.04 \%$ \\
\hline 5 & Very Poor & $<21$ & 1 & $2.78 \%$ \\
\hline \multicolumn{3}{|c|}{ Total } & $\mathbf{3 6}$ & $\mathbf{1 0 0 \%}$ \\
\hline Mean Score & & $\mathbf{4 4 . 6 7}$ \\
\hline
\end{tabular}


The data above showed that Present Perfect Tense is a problematic material of English because the mean score of the test was 44.67, which was classified as enough classification. This result was an unsatisfied score since it was lower than 50. Moreover, the data also presented that there were six students (16.6\%) were classified into an outstanding level. Then only one student $(2.78 \%)$ gained both in good and very poor levels. Ten students $(27.8 \%)$ were at a reasonable level, and eighteen students $(50.04 \%)$ were in less classification. The data were as proof that the students did not master the Present Perfect Tense yet.

The students' ability in using the Present Perfect Tense based on the indicators were as in the following table:

Table 4 The Students' Indicators Test Results

\begin{tabular}{|c|l|c|c|}
\hline No & Assessment Indicators & Mean Score & Level Ability \\
\hline 1 & Using To Be (Has/Have) & 68.29 & Good \\
\hline 2 & Using Regular Verbs & 34.03 & Less \\
\hline 3 & Using Regular Verbs & 39.72 & Less \\
\hline
\end{tabular}

Dealing with the data, it determined that the classification of the ability in understanding To Be (Has/Have) of Present Perfect Tense was a good classification in which the mean score was 68.29. Then the knowledge in understanding of Regular Verbs was a less classification by the mean score 34.03 . Next, the ability to understanding Irregular Verbs was less classification by the mean score of 39.72. The results show that the students got difficulties in using Present Perfect Tense.

\section{Results of the Questionnaire}

The questionnaire in this research is a questionnaire of Guttmann scale type which the answer choices only "Yes" and "No". It purposed to gain the related data which support the test results.

Table 5 The Students' Results of Questionnaire

\begin{tabular}{|c|c|c|c|c|}
\hline No & Criterion & Score & Mean Score & Percentage \\
\hline 1 & Yes & 22.53 & 0.63 & $63 \%$ \\
\hline 2 & No & - & - & - \\
\hline
\end{tabular}


Based on the data obtained from the research respondents, it was determined that the percentage is more significant than $50 \%$ that is equal to $63 \%$, which can be interpreted as enough (affirmative).

\section{Results of the Interview}

The interview in this research is an unstructured interview type that would be used to get the data related to the causes of the students' difficulties in learning Present Perfect Tense. To gain the goal, the researchers needed the helping of English teachers of SMKN 1 Tembilahan. The results of the interview show that the students got difficulties because of some cases: (1) English is less favoured learning materials by the students, (2) they are lack of English vocabulary mastery, (3) they had problems in using to be (has/have) of Present Perfect Tense, and (4) they had difficulties in forming the verb forms (regular and irregular verbs).

\section{CONCLUSION}

This study was designed as survey research which aimed at investigating the students' difficulties in learning Present Perfect Tense. Concerning the data analysis, it could be concluded that their challenges included the use of to be (has/have) of Present Perfect tense, the use of verbs forms. They are caused by some cases English as less favoured learning materials, lack of English vocabulary mastery, problems in using to be (has/have) of Present Perfect Tense, and problems in forming the verb forms (regular and irregular verbs).

\section{REFERENCES}

Data Laporan Tahunan Siswa SMK Negeri 1 Tembilahan No. 335/SMKN1/KS-2017

Hermayawati. 2010. Analisis Kesulitan Belajar Bahasa Inggris Mahasiswa. Jurnal SosioHumaniora Vol. 1. No.1. September 2010. ISSN. 2087-1899

Khaljoo, Akram Inanloo. 2013. Problems in Teaching and Learning English for Students. International Journal of Engineering Research and Development. Vol. 7. Issue 3. May 2013. Pp. 56-58. www.ijerd.com 
Murphy, Raymond. 1985. English Grammar in Use with Answers. Cambridge: Cambridge University Press.

Supono, Idi. 2007. English Grammar. Jakarta: Wahyu Media

Suryani, Yulinda Erma. 2010. Kesulitan Belajar. Magistra. No. 73. Th. XXII. September 2010.

Swan, Michael. 2005. Teaching English as a Second or Foreign Language. Oxford: Oxford University Press. http//www.tesl-ej.org/ej37/r8.pdf

Wicaksono, Andre. 2010. The New Complete English Grammar. Jakarta: Pustaka Ilmu 